\title{
Influenza A virus infection of healthy piglets in an abattoir in Brazil: animal-human interface and risk for interspecies transmission
}

\author{
Ariane Ribeiro Amorim, Luz Alba Maria Garcete Fornells, \\ Felicidade da Costa Reis, Daiana Jacinto Rezende, Gabriella da Silva Mendes, \\ José Nelson dos Santos Silva Couceiro, Norma Suely de Oliveira Santos/ ${ }^{+}$
}

Instituto de Microbiologia, Universidade Federal do Rio de Janeiro, Rio de Janeiro, RJ, Brasil

\begin{abstract}
Asymptomatic influenza virus infections in pigs are frequent and the lack of measures for controlling viral spread facilitates the circulation of different virus strains between pigs. The goal of this study was to demonstrate the circulation of influenza A virus strains among asymptomatic piglets in an abattoir in Brazil and discuss the potential public health impacts. Tracheal samples $(n=330)$ were collected from asymptomatic animals by a veterinarian that also performed visual lung tissue examinations. No slaughtered animals presented with any noticeable macroscopic signs of influenza infection following examination of lung tissues. Samples were then analysed by reverse transcriptionpolymerase chain reaction that resulted in the identification of $30(9 \%)$ influenza A positive samples. The presence of asymptomatic pig infections suggested that these animals could facilitate virus dissemination and act as a source of infection for the herd, thereby enabling the emergence of influenza outbreaks associated with significant economic losses. Furthermore, the continuous exposure of the farm and abattoir workers to the virus increases the risk for interspecies transmission. Monitoring measures of swine influenza virus infections and vaccination and monitoring of employees for influenza infection should also be considered. In addition regulatory agencies should consider the public health ramifications regarding the potential zoonotic viral transmission between humans and pigs.
\end{abstract}

Key words: influenza virus - interspecies transmission - zoonosis - pork industry

Influenza A viruses are classified into the family Orthomyxoviridae. Viral particles are composed by segmented negative-sense RNA enclosed by a helical capsid and lipoprotein envelope. These viruses infect a variety of species including humans, swine, equine species, aquatic mammals and birds (Wright et al. 2007). Influenza A virus taxonomy is based on the antigenic characteristics of the two envelope glycoproteins, haemagglutinin (HA) and neuraminidase (NA). Currently, $16 \mathrm{HA}$ and nine NA subtypes have been defined (Ma et al. 2009) and a distinct influenza A virus lineage was recently detected in bats shown to carry new HA subtypes putatively designated as HA17 (Tong et al. 2012)

Influenza A viruses have remained endemic in pig populations worldwide and represent a common cause of respiratory infections in pigs (Brown 2000). The primary route of virus transmission is via pig-to-pig contact resulting in nasopharyngeal routes of infection following nasal viral secretions that are disseminated through droplets or aerosols. Coughing, nasal discharge, fever, lethargy, difficulty in breathing, depressed appetite and reproductive disorders have been associated with different influenza A virus subtype infections throughout the world (Kuntz-Simon \& Madec 2009). Close contact

doi: 10.1590/0074-0276108052013003

Financial support: CNPq, CAPES, FAPERJ

+ Corresponding author: nsantos@micro.ufrj.br

Received 20 February 2013

Accepted 30 April 2013 between pigs, stress, meteorological and environmental factors have been shown to contribute to influenza virus spread (Brown 2000, Williamson et al. 2012).

Pigs are susceptible to infections with either human or avian influenza viruses and have been suggested as intermediate hosts or mixing vessels resulting in the generation of pandemic viruses following reassortment or adaptation to the mammalian host (Ito et al. 1998, Yu et al. 2008, Ma et al. 2009, Kwon et al. 2011, Wu et al. 2011, Moreno et al. 2012). Attachment of influenza A viruses to host cells occurs through a binding pocket on the viral HA head and a terminal specific $N$-acetylneuraminic acid-galactose (NeuAc-Gal) linkage on the host cell membranes. Most influenza A viruses isolated from humans preferentially recognise NeuAca2,6Gal linkages, whereas most avian isolates preferentially recognise NeuAc $22,3 \mathrm{Gal}$. Swine viruses bind equally well to both NeuAca2,6Gal and NeuAca2,3Gal (with a slightly higher binding affinity for NeuAc $\alpha 2,6 \mathrm{Gal})$, therefore they are able to infect both human and avian cells [for review see Ma et al. (2009)]. Evidence exists demonstrating transmission of influenza viruses from humans to pigs (Howden et al. 2009, Adeola et al. 2010, Song et al. 2010, Forgie et al. 2011, Gray et al. 2012, Williamson et al. 2012) as well as from pigs to humans (Robinson et al. 2007, Yassine et al. 2009, CDC 2012). Influenza A virus transmission between humans and swine often results in the emergence of new strains with the potential of spreading among both populations (Myers et al. 2007, Yassine et al. 2009, Xu et al. 2011, Yu et al. 2011).

Studies have shown that swine workers are at an increased risk of contracting an influenza $\mathrm{A}$ infection 
from pigs (Olsen et al. 2002, Myers et al. 2006, Gray et al. 2007, Yassine et al. 2009, Beaudoin et al. 2012, CDC 2012). Biosecurity and biocontainment measurements might help prevent the spread of pathogens, including influenza viruses from pigs to humans and vice-versa. Personal protective equipment (PPE) and proper hygiene practices are recommended for persons with potential exposures to livestock infected with influenza (CDC 2010). However, the most effective protective measure would be to vaccinate both pigs and workers (CDC 2010).

The goal of this work was to demonstrate the circulation of influenza A viruses among asymptomatic piglets in an abattoir in the state of Minas Gerais (MG), Brazil, and discuss its potential impact on public health.

\section{MATERIALS AND METHODS}

Specimens - Tracheal swabs $(\mathrm{n}=330)$ were collected from apparently healthy pigs in an abattoir in MG between September 2009-September 2011. The samples were collected after the animals were slaughtered and samples were preserved in viral transport medium (VTM) containing RNAlater ${ }^{\circledR}$ (Life technologies, Austin, TX, USA) and transported in a cooler to the laboratory for influenza A virus detection.

RNA extraction and reverse transcription-polymerase chain reaction (RT-PCR) amplification - Viral RNA was extracted from $300 \mu \mathrm{L}$ of respective samples in VTM using the Totally RNA Kit (Applied Biosystems, Foster City, CA, USA), according to the manufacturer's recommendations. RT-PCR and nested-PCR amplifications were performed using specific primers designed to amplify a conserved influenza $\mathrm{A}$ virus $\mathrm{M}$ gene region as described previously (Ellis \& Zambon 2001).

To confirm the specificity of the PCR products, the amplified DNA of positive, randomly selected samples were purified using the Wizard SV gel and PCR CleanUp system kit (Promega, Madison, WI, USA) and the sequences determined using the BigDye ${ }^{\circledR}$ Terminator Cycle Sequencing Kit and the ABI PRISM ${ }^{\circledR} 3100$ automated DNA sequencer (Applied Biosystems). DNA sequences were edited using the Chromas software (Technelysium Pty Ltd, Australia) and compared to DNA sequences available in GenBank (ncbi.nlm.nih.gov) using the BLAST tool (ncbi.nlm.gov/BLAST).

Ethics - The Animal Ethics Committees of the Federal University of Rio de Janeiro, Rio de Janeiro, Brazil, approved the study protocol.

\section{RESULTS}

Tracheal swabs $(n=330)$ were collected from 180 day-old piglets weighting approximately $110 \mathrm{Kg}$. Study animals were never vaccinated against influenza viruses and at the time of sample collection no animal presented with any clinical respiratory signs of disease. Samples were collected by a trained veterinarian that also performed a gross visual examination of the lung tissues. None of the slaughtered animals presented with any noticeable macroscopic signs of influenza infection.

Of the 330 samples examined, 47 samples were collected in 2009, 183 in 2010 and 100 in 2011. Thirty sam- ples $(9 \%)$ were positive for influenza A virus by RT-PCR analysis directed to the $\mathrm{M}$ protein encoding gene (Table). Sequence analysis confirmed the specificity of the assay and therefore the detection of influenza A virus (data not show). The yearly frequency of influenza virus infections was $12.8 \%$ in $2009,9.8 \%$ in 2010 and $6 \%$ in 2011.

The conditions of the abattoir regarding biosecurity, biocontainment and use of PPE were analysed. The workers reported that on average 50 animals brought in from different farms in the region (and housed together in a pre-slaughter area for 3-5 days) were slaughtered weekly. Workers involved in animal feeding and slaughtering used special footwear and clothing (disposable coveralls), but no goggles, masks or gloves (Fig. 1). Antiinfluenza vaccination was neither mandatory nor reported for either animals or workers. A pet cat lived in the abattoir area that had access to animal waste (Fig. 2).

\section{DISCUSSION}

In this study, the prevalence of subclinical influenza A virus infections was $9 \%$. It was not possible to obtain information regarding handling procedures used by respective suppliers of the animals slaughtered during the study period. However, it is clear that these animals represented a source for influenza viruses with the potential of causing infections in otherwise healthy animals resulting in significant economic losses. Although clinical disease is associated with low mortality rates, infections result in high rates of morbidity, causing primarily loss of herd productivity and weight loss. Recent evidence of viral spread among populations of asymptomatically infected pigs showed the significant health risk this possess for the pig industry (Forgie et al. 2011, Bowman et al. 2012, Gray et al. 2012, Wong et al. 2012). In Brazil, seroepidemiological evidence demonstrated the spread of influenza A virus among pig herds. A serological survey performed in $\mathrm{MG}$ demonstrated that $44.5 \%$ and $10.1 \%$ of surveyed animals were positive for swine influenza virus strains belonging to subtypes $\mathrm{H} 1 \mathrm{~N} 1$ and $\mathrm{H} 3 \mathrm{~N} 2$, respectively, and $38.3 \%$ were positive for human

\section{TABLE}

Swine influenza virus detection in tracheal swabs collected from asymptomatic pigs from an abattoir in the state of Minas Gerais, Brazil, between September 2009-September 2011

\begin{tabular}{cccc}
\hline \multicolumn{4}{c}{ Detection of influenza A virus } \\
\cline { 2 - 4 } Year & $\begin{array}{c}\text { Positive } \\
\text { samples } \\
(\mathrm{n})\end{array}$ & $\begin{array}{c}\text { Negative } \\
\text { samples } \\
(\mathrm{n})\end{array}$ & $\begin{array}{c}\text { Positive } \\
(\%)\end{array}$ \\
\hline 2009 & 6 & 41 & 12.8 \\
2010 & 18 & 165 & 9.8 \\
2011 & 6 & 94 & 6 \\
\hline Total & 30 & 300 & 9 \\
\hline
\end{tabular}


influenza strain H1N1 (Rajão et al. 2012). Another study of pig farms located in eight different states in the South, Southeast and Midwest Regions of Brazil demonstrated that $16.7 \%$ and $2.2 \%$ of the surveyed animals possessed antibodies against human influenza viruses subtypes H3N2 and H1N1, respectively (Brentano et al. 2002).

Transmission of influenza viruses from pigs to humans has been reported occasionally, but most cases result in mild infections rarely resulting in death (Robinson et al. 2007, Howden et al. 2009, Yassine et al. 2009, Adeola et al. 2010, Song et al. 2010, Forgie et al. 2011, CDC 2012, Gray et al. 2012, Williamson et al. 2012). Swine workers and their family members are at increased risk of contracting swine influenza virus infections (Olsen et al. 2002, Myers et al. 2006, Gray et al. 2007, Robinson et al. 2007, Yassine et al. 2009, Beaudoin et al. 2012, CDC 2012, Wong et al. 2012). In this study, we were unable to document human flu-like illnesses during the period of sample collection. However, continuous exposure of the farm and abattoir workers to animals suffering from subclinical influenza virus infections provided an environment conducive to the occurrence of interspecies infections and the emergence of new potentially pathogenic viral variants.

Recently, Gray et al. (2012) found a 19\% prevalence of influenza A viruses among 57 show pigs swabbed during the 2009 Minnesota State Fair during the second wave of the 2009 pandemic. Even though molecular analyses or viral cultures identified the presence of influenza A
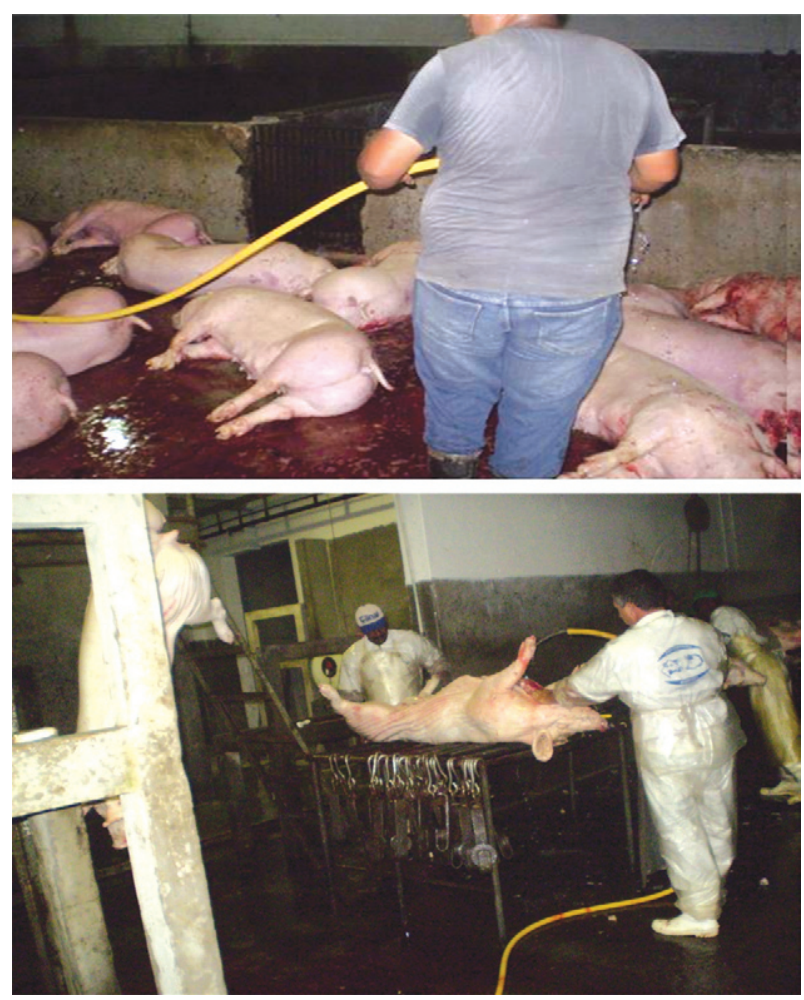

Fig. 1: abattoir employees involved in animal feeding and slaughtering. Workers used special footwear and disposable coveralls, but no goggles, masks or gloves. virus infection, no pigs presented with clinical signs of influenza illness at the time of sampling, suggesting that exposure to apparently healthy pigs at shows could result in influenza A virus transmission. A survey of individuals working with pigs at the fair identified two persons presenting with influenza-like illness within a seven day period after the fair: an adult, with onset one day after his pigs arrived at the fair (and 4 days before pig swabbing) and his daughter who developed an illness on the last day of the fair (3 days after pig swabbing). In addition, three pigs exhibited by the child tested positive for influenza A viruses (Gray et al. 2012).

Wong et al. (2012) reported a case of an influenza A H3N2 variant $(\mathrm{H} 3 \mathrm{~N} 2 \mathrm{v})$ infection in a child who attended an agricultural fair in Pennsylvania, United States of America (USA), in 2011. A retrospective cohort study among members of an agricultural club who attended the fair identified two other confirmed cases, four probable and 82 suspected cases. Among the study members, the risk for suspected case status increased as swine exposure increased from no exposure $(4 \%)$, visiting swine exhibits $(8 \%)$ and touching swine $(16 \%)$. This study concluded that fairs may serve as venues for zoonotic transmission of viruses with epidemic potential; therefore health officials should investigate respiratory illness outbreaks associated with agricultural events (Wong et al. 2012).

A study conducted by Bowman et al. (2012) demonstrated that $22.3 \%$ of exhibit pigs at agricultural fairs in Ohio, USA, between 2009-2011, were asymptomatically infected with influenza A viruses. The study concluded that subclinical influenza virus A infections in pigs at agricultural fairs may pose a risk to human health and create challenges for passive surveillance programs for influenza virus A in swine herds.

Shinde et al. (2009) reported 11 cases of infection with triple-reassortant swine influenza A (H1) viruses in persons with exposures to pigs in the USA, before the human epidemic caused by influenza viruses of swine-origin.

A survey of the literature conducted by Myers et al. (2007) found 50 cases of apparent zoonotic swine influ-

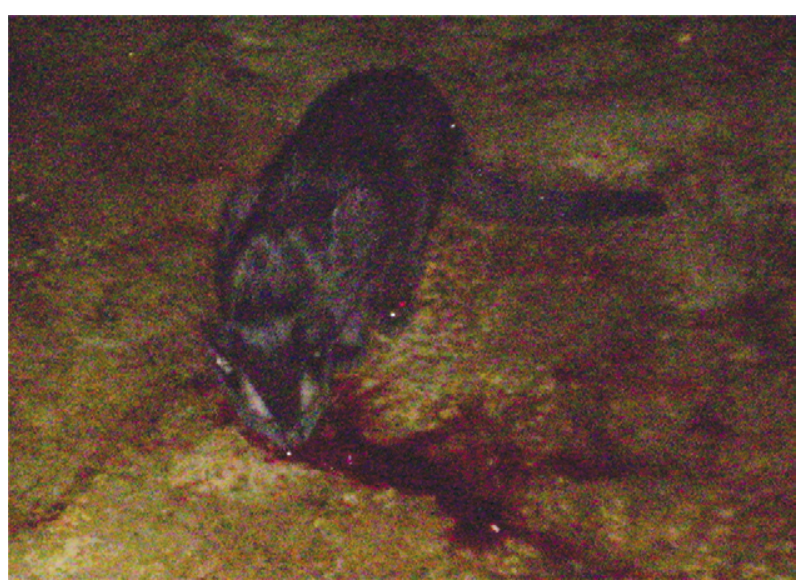

Fig. 2: pets living in the abattoir area in contact with the animal waste. 
enza virus infections involving civilians and military personnel. Most civilian subjects reported exposures to swine. Myers et al. (2006) also observed that occupational exposures may also play important roles in the mixing vessel hypothesis. That study demonstrated that farmers, meat processing workers and veterinarians presented with significantly elevated anti-swine influenza titres compared to control subjects.

Forgie et al. (2011) investigated a human and swine influenza outbreak at a swine research farm in Alberta, Canada, and reported human-to-swine transmission and subsequent influenza epidemics in both pig and human populations. Sixty-seven percent of humans and $94 \%$ of swine with positive laboratory tests results had few or no symptoms (Forgie et al. 2011).

Until 2005, sustained circulation of human viruses in pig populations was uncommon. Since then, swine influenza virus strains resulting from reassortment events containing HA gene segments of human origin have been detected (Ma et al. 2009) and the development of weak immune responses against homologous and heterologous strains may be the cause of recurrent infections. It was also observed that infections could occur in piglets even in presence of colostral-derived antibodies against virus subtypes circulating between farm animals (Simon-Grifé et al. 2012).

Several studies have demonstrated the circulation of influenza viruses among pets, particularly cats and dogs. Transmission and subclinical infection of human and avian H3N2 (Houser \& Heuschele 1980, Song et al. 2008), equine H3N8 (Crawford et al. 2005), avian H5N1 (Songserm et al. 2006b) and the pandemic 2009 H1N1 (Damiani et al. 2012) influenza virus strains to dogs have been documented. Serological evidence of naturally acquired infections caused by seasonal human H1N1 and H3N2 (Ali et al. 2011), the pandemic 2009 H1N1 (Sponseller et al. 2010, Ali et al. 2011), and the avian H5N1 (Songserm et al. 2006a) influenza virus strains in cats have also been reported. Generally animals show no signs of influenza, although symptomatic infections have been described (Songserm et al. 2006a, b, Harder \& Vahlenkamp 2010, Sponseller et al. 2010). Interspecies transmission of canine influenza virus subtype H3N2 to domestic cats has also been described (Song et al. 2011).

Circulation of influenza viruses among companion animals increases the chances of animal-human transmission. A study conducted among pig farms in Malaysia evaluated risk factors associated with swine influenza H1N1 and H3N2 viruses. This study showed that the presence of pet mammals on the farm (such as cats) significantly increased the probability of infection. Pigs from farms where no pets were observed were about 32 times less likely to be seropositive for H1N1 influenza virus compared to pigs raised in farms where cats were present (Suriya et al. 2008). In this study, we observed the presence of a cat in the abattoir area living in close contact with pigs and humans, creating a perfect environment for zoonotic influenza virus transmission.

Interestingly, despite the damage caused by influenza virus infections, these types of infections are not routinely monitored in pig farms (Gray \& Baker 2011).
The diagnosis of symptomatic influenza virus infections in pigs has been based mainly on clinical signs and histopathological lesions (not present in subclinical infections). However, once the animal is a virus carrier it becomes a source of viral spread regardless of their clinical status. Despite this animal be deemed suitable for the slaughter, it can contaminate other farm animals that may develop the disease. In addition, the infected animals can also contaminate human beings who are directly involved in the pig handling.

Currently, Brazil is the fourth largest global trader of pig meat with an estimated pig population of 38 million animals. In 2011, Brazil exported over 500 million tons of pork to 60 countries worldwide (ABIPECS 2011). The standards for the slaughter of pigs are strict and designed to minimise the spread of pathogens. In Brazil, pig slaughter methods and meat handling are regulated by the Ministry of Agriculture, Livestock and Supply (MAPA). This agency regulates procedures implemented before and after slaughter (ante-mortem and post-mortem) (MAPA 1995). However, MAPA does not require the implementation of PPE or vaccination of the abattoir workers. Since pig farming represents a major source of income for Brazil, implementation of monitoring measures for the identification of pig influenza virus infections would be fundamental to improving the productive parameters of this industry. Similarly, taking into account that influenza viruses can also be transmitted to humans through pigs, vaccination and monitoring of employees for infection should be considered. In addition, the potential of zoonotic transmission between humans, pigs and pets should raise public health concerns that should be considered by regulatory agencies.

\section{ACKNOWLEDGEMENTS}

To Alessandra Ribeiro Amorim and Roberto Augusto Albanese de Castro, for assistance during sample collection, and to Soluza dos Santos Gonçalves, for technical assistance during sample testing.

\section{REFERENCES}

ABIPECS - Associação Brasileira da Indústria Produtora e Exportadora de Carne Suína 2011. Relatórios anuais da Associação Brasileira da Indústria Produtora e Exportadora de Carne Suína. Available from: abipecs.org.br/uploads/relatorios/relatoriosassociados/ABIPECS_relatorio_2011_pt.pdf.

Adeola OA, Adeniji JA, Olugasa BO 2010. Detection of haemagglutination-inhibiting antibodies against human $\mathrm{H} 1$ and $\mathrm{H} 3$ strains of influenza A viruses in pigs in Ibadan, Nigeria. Zoonoses Public Health 57: 89-94.

Ali A, Daniels JB, Zhang Y, Rodriguez-Palacios A, Hayes-Ozello K, Mathes L, Lee CW 2011. Pandemic and seasonal human influenza virus infections in domestic cats: prevalence, association with respiratory disease and seasonality patterns. J Clin Microbiol 49: 4101-4105

Beaudoin A, Johnson S, Davies P, Bender J, Gramer M 2012. Characterization of influenza A outbreaks in Minnesota swine herds and measures taken to reduce the risk of zoonotic transmission. Zoonoses Public Health 59: 96-106.

Bowman AS, Nolting JM, Nelson SW, Slemons RD 2012. Subclinical influenza virus A infections in pigs exhibited at agricultural fairs, Ohio, USA, 2009-2011. Emerg Infect Dis 18: 1945-1950. 
Brentano L, Ciacci-Zanella JR, Mores N, Piffer IA 2002. Levantamento soroepidemiológico para coronavírus respiratório e da gastroenterite transmissivel e dos vírus de influenza H3N2 e H1N1 em rebanhos suínos no Brasil, Ministério da Agricultura, Pecuária e Abastecimento, Concórdia, 306 pp.

Brown IH 2000. The epidemiology and evolution of influenza viruses in pigs. Vet Microbiol 74: 29-46.

CDC - Centers for Disease Control and Prevention 2010. CDC interim guidance for people who have close contact with pigs in non-commercial settings: preventing the spread of influenza A viruses, including the novel influenza A (H1N1) virus. Available from: cdc.gov/h1n1flu/guidelines_noncommercial_settings_with_pigs. htm\#f.

CDC - Centers for Disease Control and Prevention 2012. Notes from the field: outbreak of influenza A (H3N2) virus among persons and swine at a county fair - Indiana, July 2012. MMWR Morb Mortal Wkly Rep 61: 561.

Crawford PC, Dubovi EJ, Castleman WL, Stephenson I, Gibbs EP, Chen L, Smith C, Hill RC, Ferro P, Pompey J, Bright RA, Medina MJ, Johnson CM, Olsen CW, Cox NJ, Klimov AI, Katz JM, Donis RO 2005. Transmission of equine influenza virus to dogs. Science 310: 482-485.

Damiani AM, Kalthoff D, Beer M, Müller E, Osterrieder N 2012. Serological survey in dogs and cats for influenza A (H1N1)pdm09 in Germany. Zoonoses Public Health 59: 549-552.

Ellis JS, Zambon MC 2001. Combined PCR-heteroduplex mobility assay for detection and differentiation of influenza A viruses from different animal species. J Clin Microbiol 39: 4097-4102.

Forgie SE, Keenliside J, Wilkinson C, Webby R, Lu P, Sorensen O, Fonseca K, Barman S, Rubrum A, Stigger E, Marrie TJ, Marshall F, Spady DW, Hu J, Loeb M, Russell ML, Babiuk LA 2011. Swine outbreak of pandemic influenza A virus on a Canadian research farm supports human-to-swine transmission. Clin Infect Dis 52: 10-18.

Gray GC, Baker WS 2011. Editorial commentary: the problem with pigs: it's not about bacon. Clin Infect Dis 52: 19-22.

Gray GC, Bender JB, Bridges CB, Daly RF, Krueger WS, Male MJ, Heil GL, Friary JA, Derby RB, Cox NJ 2012. Influenza A (H1N1) virus among healthy show pigs, United States. Emerg Infect Dis 18: 1519-1521.

Gray GC, McCarthy T, Capuano AW, Setterquist SF, Olsen CW, Alavanja MC 2007. Swine workers and swine influenza virus infections. Emerg Infect Dis 13: 1871-1878.

Harder TC, Vahlenkamp TW 2010. Influenza virus infections in dogs and cats. Vet Immunol Immunopathol 134: 54-60.

Houser RE, Heuschele WP 1980. Evidence of prior infection with influenza A/Texas/77 (H3N2) virus in dogs with clinical parainfluenza. Can J Comp Med 44: 396-402.

Howden KJ, Brockhoff EJ, Caya FD, McLeod LJ, Lavoie M, Ing JD, Bystrom JM, Alexandersen S, Pasick JM, Berhane Y, Morrison ME, Keenliside JM, Laurendeau S, Rohonczy EB 2009. An investigation into human pandemic influenza virus (H1N1) 2009 on an Alberta swine farm. Can Vet J 50: 1153-1161.

Ito T, Couceiro JN, Kelm S, Baum LG, Krauss S, Castrucci MR, Donatelli I, Kida H, Paulson JC, Webster RG, Kawaoka Y 1998. Molecular basis for the generation in pigs of influenza A viruses with pandemic potential. $J$ Virol 72: 7367-7373.

Kuntz-Simon G, Madec F 2009. Genetic and antigenic evolution of swine influenza viruses in Europe and evaluation of their zoonotic potential. Zoonoses Public Health 56: 310-325.

Kwon TY, Lee SS, Kim CY, Shin JY, Sunwoo SY, Lyoo YS 2011. Genetic characterization of H7N2 influenza virus isolated from pigs. Vet Microbiol 153: 393-397.
Ma W, Lager KM, Vincent AL, Janke BH, Gramer MR, Richt JA 2009. The role of swine in the generation of novel influenza viruses. Zoonoses Public Health 56: 326-337.

MAPA - Ministério da Agricultura, Pecuária e Abastecimento 1995. Normas técnicas de instalações e equipamentos para abate e industrialização de suínos. Available from: extranet. agricultura.gov.br/sislegis- consulta/consultarLegislacao.do? operacao $=$ visualizar\&id $=1281$.

Moreno A, Chiapponi C, Boniotti MB, Sozzi E, Foni E, Barbieri I, Zanoni MG, Faccini S, Lelli D, Cordioli P 2012. Genomic characterization of H1N2 swine influenza viruses in Italy. Vet Microbiol 156: 265-276.

Myers KP, Olsen CW, Gray GC 2007. Cases of swine influenza in humans: a review of the literature. Clin Infect Dis 44: 1084-1088.

Myers KP, Olsen CW, Setterquist SF, Capuano AW, Donham KJ, Thacker EL, Merchant JA, Gray GC 2006. Are swine workers in the United States at increased risk of infection with zoonotic influenza virus? Clin Infect Dis 42: 14-20.

Olsen CW, Brammer L, Easterday BC, Arden N, Belay E, Baker I, Cox NJ 2002. Serologic evidence of H1 swine influenza virus infection in swine farm residents and employees. Emerg Infect Dis 8: 814-819.

Rajão DS, Alves F, del Puerto HL, Braz GF, Oliveira FG, GiacciZanella JR, Schaefer R, Reis JKP, Guedes RMC, Lobato ZIP, Leite RC 2012. Serological evidence of swine Influenza in Brazil. Influenza Other Respi Viruses 7: 109-112.

Robinson JL, Lee BE, Patel J, Bastien N, Grimsrud K, Seal RF, King R, Marshall F, Li Y 2007. Swine influenza (H3N2) infection in a child and possible community transmission, Canada. Emerg Infect Dis 13: 1865-1870.

Shinde V, Bridges CB, Uyeki TM, Shu B, Balish A, Xu X, Lindstrom S, Gubareva LV, Deyde V, Garten RJ, Harris M, Gerber S, Vagasky S, Smith F, Pascoe N, Martin K, Dufficy D, Ritger K, Conover C, Quinlisk P, Klimov A, Bresee JS, Finelli L 2009. Triple-reassortant swine influenza A (H1) in humans in the United States, 2005-2009. N Engl J Med 360: 2616-2625.

Simon-Grifé M, Martín-Valls GE, Vilar MJ, Busquets N, Mora-Salvatierra M, Besterbroer TM, Fouchier RA, Martín M, Mateu E, Casal J 2012. Swine influenza virus infection dynamics in two pig farms: results of a longitudinal assessment. Vet Res 43: 7-11.

Song D, Kang B, Lee C, Jung K, Ha G, Kang D, Park S, Park B, Oh J 2008. Transmission of avian influenza virus (H3N2) to dogs. Emerg Infect Dis 14: 741-746.

Song DS, Na DJ, Moon HJ, Yeom MJ, Jeong HY, Jeong WS, Park SJ, Kim HK, Han SY, Oh JS, Park BK, Kim JK, Poo H, Webster RG, Jung K, Kang BK 2011. Interspecies transmission of the canine influenza H3N2 virus to domestic cats in South Korea, 2010. J Gen Virol 92: 2350-2355.

Song MS, Lee JH, Pascua PN, Baek YH, Kwon HI, Park KJ, Choi HW, Shin YK, Song JY, Kim CJ, Choi YK 2010. Evidence of human-to-swine transmission of the pandemic (H1N1) 2009 influenza virus in South Korea. J Clin Microbiol 48: 3204-3211.

Songserm T, Amonsin A, Jam-on R, Sae-Heng N, Meemak N, Pariyothorn N, Payungporn S, Theamboonlers A, Poovorawan Y 2006a. Avian influenza H5N1 in naturally infected domestic cat. Emerg Infect Dis 12: 681-683.

Songserm T, Amonsin A, Jam-on R, Sae-Heng N, Pariyothorn N, Payungporn S, Theamboonlers A, Chutinimitkul S, Thanawongnuwech R, Poovorawan Y 2006b. Fatal avian influenza A H5N1 in a dog. Emerg Infect Dis 12: 1744-1747.

Sponseller BA, Strait E, Jergens A, Trujillo J, Harmon K, Koster L, Jenkins-Moore M, Killian M, Swenson S, Bender H, Waller K, 
Miles K, Pearce T, Yoon KJ, Nara P 2010. Influenza A pandemic (H1N1) 2009 virus infection in domestic cat. Emerg Infect Dis 16: $534-537$

Suriya R, Hassan L, Omar AR, Aini I, Tan CG, Lim YS, Kamaruddin MI 2008. Seroprevalence and risk factors for influenza A viruses in pigs in Peninsular Malaysia. Zoonoses Public Health 55: $342-351$.

Tong S, Li Y, Rivailler P, Conrardy C, Castillo DA, Chen LM, Recuenco S, Ellison JA, Davis CT, York IA, Turmelle AS, Moran D, Rogers S, Shi M, Tao Y, Weil MR, Tang K, Rowe LA, Sammons S, Xu X, Frace M, Lindblade KA, Cox NJ, Anderson LJ, Rupprecht CE, Donis RO 2012. A distinct lineage of influenza A virus from bats. Proc Natl Acad Sci 109: 4269-4274.

Williamson SM, Bidewell CA, Tucker AW, McCrone IS, Wood JL, Brons N, Habernoll H, Essen SC, Brown IH 2012. Descriptive clinical and epidemiological characteristics of influenza A H1N1 2009 virus infections in pigs in England. Vet Rec 171: 271-278.

Wong KK, Greenbaum A, Moll ME, Lando J, Moore EL, Ganatra R, Biggerstaff M, Lam E, Smith EE, Storms AD, Miller JR, Dato V, Nalluswami K, Nambiar A, Silvestri SA, Lute JR, Ostroff S, Hancock K, Branch A, Trock SC, Klimov A, Shu B, Brammer L, Epperson S, Finelli L, Jhung MA 2012. Outbreak of influenza A (H3N2) variant virus infection among attendees of an agricultural fair, Pennsylvania, USA, 2011. Emerg Infect Dis 18: 1937-1944.
Wright PF, Neumann G, Kawaoka Y 2007. Orthomyxoviruses. In DM Knipe, PM Howley, DE Griffin, RA Lamb, MA Martin, B Roizman, SE Straus, Fields virology, 5th ed., Lippincott/Williams and Wilkins, Philadelphia, p. 1691-1740.

Wu R, Liu Z, Liang W, Yang K, Deng J, Duan Z, Zhou D, Xu D 2011. Serological and virological surveillance of swine H1N1 and H3N2 influenza virus infection in two farms located in Hubei province, central China. Zoonoses Public Health 58: 508-513.

Xu M, Huang Y, Chen J, Huang Z, Zhang J, Zhu Y, Xie S, Chen Q, Wei W, Yang D, Huang X, Xuan H, Xiang H 2011. Isolation and genetic analysis of a novel triple-reassortant H1N1 Influenza virus from a pig in China. Vet Microbiol 147: 403-409.

Yassine HM, Khatri M, Zhang YJ, Lee CW, Byrum BA, O'Quin J, Smith KA, Saif YM 2009. Characterization of triple reassortant H1N1 influenza A viruses from swine in Ohio. Vet Microbiol 139: 132-139.

Yu H, Hua RH, Wei TC, Zhou YJ, Tian ZJ, Li GX, Liu TQ, Tong GZ 2008. Isolation and genetic characterization of avian origin H9N2 influenza viruses from pigs in China. Vet Microbiol 131: 82-92.

Yu H, Zhou YJ, Li GX, Ma JH, Yan LP, Wang B, Yang FR, Huang M, Tong GZ 2011. Genetic diversity of H9N2 influenza viruses from pigs in China: a potential threat to human health? Vet Microbiol 149: 254-261. 